\title{
HOUSING AS SOCIAL ASSISTANCE
}

by

Shem Curtis, BSW, University of the West Indies, 2001

\begin{abstract}
An MRP
Presented to Ryerson University
\end{abstract}

In partial fulfillment of the

Requirements for the degree of

Master of Social Work

In the Program of

Social Work

Toronto, Ontario, Canada, 2018

(C) Shem Curtis 2018 


\section{AUTHOR'S DECLARATION FOR ELECTRONIC SUBMISSION OF A MRP}

I hereby declare that I am the sole author of this MRP. This is a true copy of the MRP, including any required final revisions.

I authorize Ryerson University to lend this MRP to other institutions or individuals for the purpose of scholarly research

I further authorize Ryerson University to reproduce this MRP by photocopying or by other means, in total or in part, at the request of other institutions or individuals for the purpose of scholarly research.

I understand that my MRP may be made electronically available to the public. 


\begin{abstract}
This Major Research Paper conducted analysis of social housing policies and regulations in Ontario from 1993 to present. It was done to unearth the dominant discourses that informed social housing policies. Through a review of the Literature, a broader perspective will be had on social housing as well as social assistance, of which is deeply intertwined with social housing. The lack of a national strategy on social housing has caused Toronto to adopt a more entrepreneurial approach to housing, using public private partnerships, social mix revitalization initiatives, and other market and third sector influenced development mechanisms.

Social policy has been neoliberalized in Ontario at least since the advent of the 'Common Sense Revolution' in 1995, when a Conservative government was elected on a platform of neoliberal reform. Since then social housing has not been given the priority it deserves even with the changing of government and promises to address the lack of affordable housing in Toronto.

These findings highlight difficulties on the part of Toronto to develop new affordable housing at a time when the city continues to grow and demand for housing is increasing. The visibility of homelessness across the city suggest policy failures and a need to act, to address the problem of lack of affordable housing post haste.
\end{abstract}




\section{TABLE OF CONTENTS}

CHAPTER

PAGE

Chapter 1 - Introduction

Chapter 2 - Literature Review

Chapter 3 - Theoretical Framework

Chapter 4 - Methodology

Chapter 5 - Discussions/Findings

23

Chapter 6 - Analysis

39

Chapter 7 - Conclusion

43

References

45 


\section{LIST OF FIGURES}

Figure 1: Withdrawal of federal funding for social housing in the City of Toronto, 2001-2029

Figure 2: $\quad$ Relative cost per room of housing in the city of Toronto's (Canada) mixed-use zone Figure 3: Income limit for the units at 110 River St 


\section{CHAPTER 1}

\section{Introduction}

Toronto is the largest city in Canada and has experience an estimated $17.1 \%$ increase in population growth from 2007 to 2017(Statistic Canada, 2018). This would suggest that Toronto is a magnet for new comers. For low-income families who call Toronto home, one thing is certain, they are spending more than the recommended amount to keep a roof over their head. According to a report from the City of Toronto, Titled Rental Housing Market Condition (2018) “for precisely 47 percent of 'Torontonians who do not own home, more than a third of their income goes to rent” (p.2). A number that the agency labels as "unaffordable”, it recommends that one should spend no more than 30 percent of one’s income on housing.

The auditor general report on housing in 2017 also paints a bleak picture for social housing in Ontario. The report states “Ontario’s social housing wait list of 185,000 households (about 481,000 people).This representing about 3.4\% of the province's total population, is one of the largest in Canada relative to the population size of other provinces (p.2). Social housing is therefore important for many, as it provides affordable housing to poor families whose income are often times insufficient to purchase necessary food items as well as to pay rent.

The issue of affordability did not crop up overnight. As such, this research analysis begins from 1993 a significant watershed moment for social housing as the Federal government of Canada transferred responsivity for social housing to Provincial authorities. This later lead to the passage of the passage of the Social Housing Reform Act 2000, which required municipalities to assume responsibility for social housing (Ministry of Municipality and Housing Affair). The significance of the offloading has meant a reduction in funds available for social housing. Coupled with an exponential increase in municipal housing expenditures, rising from some \$145 million in 1997 
to over $\$ 1.5$ billion in 2008 (Statistics Canada, 2009). Municipalities are therefore finding it hard to fund social housing projects. Cities such as Toronto have witnessed the intensification of an affordable housing crisis. More than 640,000 Torontonians including seniors, people with disabilities and recent immigrants, require some form of assistance in meeting their housing needs (City of Toronto, 2009). Of these, 216,000 households are in core housing need with some 66,000 currently on the social housing waiting list (City of Toronto, 2011).

Despite the problems that persist in providing affordable housing, there is still consensus among government officials irrespective of political affiliation that government has a moral responsibility to help poor families. There is however little agreement relating to the form this help should take and how long help should last. There have been attempts to forged partnership with private entities and the Toronto Housing Cooperation does provide subsidies in the form of rent-geared to income for social housing recipients with some amount of success.

Ideology(s) that shapes policies and regulations create realities for low-income families seeking affordable housing. Canada housing policies over the last 10 to 20 years reflects a belief that economic and social policies are increasingly interdependent. One where the private market is seen as inefficient in taking care of social needs as such the state steps in, play a redistributive role, and ensure there is a safety net for marginalized citizens.

Since government plays such an important role in policy development, governmentality has been used as a theoretical framework to better understand the thinking behind social policies. Esping Anderson (1990) as quoted in Hay (2009) believes that a better understand of social policy development and spending in developed societies can only come about by an examination of the three typologies of welfare states---liberal, conservative and social democratic. The distinction 
and thinking behind these three-ideological positions of government ultimately gives us an idea as to how much responsibility government is willing to assume in its effort to help poor families.

A thematic analysis is used in a later chapter to bring out some of the dominant ideas in the policies through a Foucauldian discourse framework. The thematic analysis will ultimately give rise to the body of the study or narrative that follows. It is also hoped that link will be made between social housing and the wider social assistance debate. The intention is to see housing through a social assistance lens, especially in the context of Toronto where people spend a disproportionate amount of their income on housing cost. For this study, this research will be centered on Toronto a city that faces tremendous challenges in providing affordable housing for its inhabitants. 


\section{CHAPTER 2}

\section{Literature Review}

This study will further advance social housing research by looking at policies that have influenced this critical area for poverty reduction in Toronto. It is critical to conduct such a study, as with an ever-increasing population there is the risk that more low-income families will be at risk for poverty.

\section{Main Themes}

\section{Welfare States}

Canada along with the USA, Australia and the UK have been commonly classified as liberal welfare states. Canada along with the above listed states have committed to protect the health and well-being of its citizens, especially those in financial or social need. In keeping with this model, a significant amount of the countries GDP is allocated to social programs. The whole idea of a welfare state presupposes that respective government will assume some role in taking care of its most vulnerable citizens. The reach of this role is defined by each sovereign state and in most cases looks different from state to state in practical application.

The Canadian welfare state is reliant on an asset base policy to fulfill its welfare obligations. Rothwell and Robinson (2018) have observed that Canadian social policies in general are particularly geared towards asset accumulation across the life course (p.18). This is particularly true as it relates to affordable housing, ownership was always encouraged as a means of asset accumulation than other forms of tenure. The emphasis on home ownership has ignore the economic reality of low-income families in Toronto. It is challenging for these families to qualify for mortgages or to continue to sustain mortgages if they manage to secure one. 
If we compare events in the U.S, we see that Government historically assumed responsibility for the very poor. As early as 1798 , the Federal government of the U.S provided pension for disabled veterans of the Revolutionary War. Nevertheless, in later years during the $19^{\text {th }}$ century States and local governments assumed responsibility for welfare provision. Nowadays the USA still operate welfare programs (social security, medical aid) but the general idea is that government should limit itself to creating an environment that allow everyone to prosper.

The idea of a "welfare wall" in the Canadian context did get worthy mention (Stairs 1999). In its simplest form welfare wall refers to the disincentive to work that is created by social assistance and personal income tax. Low-income families who receives social assistance and then choose to work in low paying jobs may be worst off than before, with higher income and pay roll taxes, coupled with added cost to get to and from work. Welfare programs that have work incentive element might not be attractive to low-income families who cannot secure high paying jobs. It is however, felt that if tax credits are used both as means tested and income tested it could help in lowering the welfare wall.

Researchers who looked at the impact of globalization on welfare states found the term globalization difficult to define and ever harder to analyse. Yeats (2001) for one believes that globalization has been used in so many ways and applied to so many contexts that it lacks analytical construct (p.628). There are divergence of opinions as to the impact of globalization on welfare states. Alber and Standing (2000) as cited in Kim \&Choi (2012) states that “competition states are replacing welfare states” (p.350). The erosion of the welfare state resonates with Robert (2016) who indicated that "globalization has gone hand in hand with government deregulation resulting in an erosion of social contract between Canadians and their government. The thinking of Government (Governmentality) and how it is operationalized 
affects the responsibility it plans to assume for welfare. Social housing for e.g. was an integral part of the Welfare State apparatus during the post-war period. What is now evident though is that Canadians will have to learn to live with a State that is far less generous in welfare provision, than they are accustomed to.

\section{Social Assistance Transfers}

The idea of taking from one group and giving to the other is at the heart of many Canadian welfare programs, redistribution is central to the idea of the welfare state. McEwen and Stewart (2014) further tells us that "Transferring income to families with children has long been a basic Canadian social policy” (p.99). By transferring resources from one group to another Government is inferring that it knows best and is acting as moral force and that it has the interest of its most vulnerable citizens at heart.

The Canadian Child Tax Benefit and the National Child Benefit (NCB) have been primarily designed to aid low-income families with children. The NCB was particularly designed to encourage parents to participate in the labour force and getting families to help themselves. The motivation behind a policy such as the NCB and its equivalent the American equivalent Earn Income Tax Credit (EITC), is to mitigate the effects of dependency and stigmatization, which is felt will occur if low-income families received social assistance for too long.

McEwan and Stewart (2014) believes that transferring income to families have been a basic social policy of the Canadian government. The central expectation has been that increased family income will improve the lives of Canadian (p.9). Another important historical reason that 
underpins the transfers to families have been the motivation to increase the fertility rate, redistributing wealth, and addressing a sense of moral obligation to children.

There seem to be a myriad of motivation(s) behind social assistance transfers which each seeking its own predetermined goal. This is understandable as according to Kwok and Tam (2010) "welfare assistance is the responsibility of provincial governments in Canada" (p.69) and each province will therefore have its own motivation when crafting policies. Although social assistance is felt to lift the income of poor families, it was pointed out by Beaulieu et al (2005) that there are concerns about "intergenerational reliance on Social assistance" (p.542) Countering the motivation of programs such as NCB and other such social assistance which has a strong welfare-to-work component. Hanson and Hanson (2010) tells us that these programs have ignored unpaid work that women do in the homes caring for children and other domestic duties (p.183). The importance of this point is that women who do work in the home have always being working.

On examining the success of social assistance programs that had a workfare element, Hanson and Hanson (2010) found that when families leave income assistance programs they did not necessarily escaped poverty because those who found paid employment usually formed part of the working poor (p.193). There seem to be an income bracket that must be achieved for persons to leave workfare programs successfully. It is understandable as in certain cities housing cost and other living cost are a large part of working income.

The research tells us, and conventional wisdom suggest that it is better for children to grow up with higher family income. McEwan and Stewart (2014) nevertheless found that income itself has a relatively small influence on child outcomes and that we cannot expect income transfers to low-income families to vastly improve child outcomes”. Additionally, even in the measurement 
of and definition, income measurement remains hard to standardize. In most of the data available income is measured based on the respondent's memory. It is therefore subject to recall error, also income measures tend to miss some type of income (private gifts, under-the-table wages or private gifts). Errors associated with rounding are also said to be common.

Milligan and Stabile (2007) points out that "tax credit typically focuses on the working poor, rather than the very poorest in society, while the poorest may be the most deserving, the loss of output generated by making transfers to them could exceed the value to society”. Overall there is no definitive conclusion on the effect of income transfers on poor families.

\section{Social Housing}

The term social housing is generally conflated by the literature reviewed with affordable housing. Nevertheless, there are those who see a definitional difference. The Homeless Hub (2017) believes that the terms affordable housing and social housing are often confused. While all social housing is affordable, the term 'social housing' refers more specifically to housing that is subsidized by a level of government". Social housing is used in all the articles as an umbrella term and includes public housing, which at a basic level means housing structures that are built by government.

The articles that had social housing as a dominant idea mainly looked at it from a historical perspective and explored its evolution. Skelton (1996) cited the Canadian Advisory Committee on reconstruction as saying, "Social housing was an integral part of the plans for the post-war construction of the welfare state in Canada” (p.192). Social housing as such formed part of the governments social welfare provision. This point is supported by other authors who also believed that social housing was produced under a nonprofit agenda from the 1970s. The federal 
government was involved in every aspect of the construction of affordable housing units and was said to be there from 'concept to construction' and post-construction. Every plan went through Ottawa, which had to give it a stamp of approval. Skelton (1996) citing (Rose, 1974) further tells us that "Despite a truly optimistic beginning, "its sweet prospect soured very quickly" (p.193). There is no consistent reason given for the souring of centralized control of social housing projects, but some authors point to poor quality of life for residents, ghettoization of residents and over-centralization in planning. From all indication the bureaucratic process that has become synonymous with government had become untenable.

The idea surrounding the provision of social housing then change, given the problems encountered by central government and partnership was sought. The Toronto Community Housing Corporation (TCHC) later, had no choice but to turn to the market to secure funding for the rehabilitation and replacement of subsidized housing projects (Moskalyk, 2008). In Toronto private -public partnership came in form of 'request for proposals', with the Toronto Community Housing Cooperating being the public body in charge. On evaluation of this venture it was found that while high income communities benefited there was no net gain in subsidized housing projects. Another solution to increase the stock of social housing that was tried was the Third Sector solution, third sector speaks to bodies that are not private or public and are usually community based (charities, cooperatives, self-help groups). The results were mixed as third sector solutions tend to do better in urban arears than other arears. According to Skelton (1996, p204) they "have negative associations with poor dwelling conditions, with the exception of crowding". 
It would seem from the foregoing that it has been difficult to find the right solution to increase the stock of social housing units. Perhaps what is needed is a combination of solutions working at the same time and not an overreliance on any one solution.

\section{Neoliberalism}

It is debatable if Canada was a bastion of equality before the ideas surrounding Neoliberalism started to find its way in social policies. What is however certain is that the interest rate shock that occurred in Canada in the 1980s served to lay the foundation for a neoliberal macroeconomic policy. The effects on the low-income family is also a moot point. Some writers such as Shields et al citing Kaemipur and Halli (2000) believes that the poor has been negatively affected in what they term "neoliberal transition"-the structural changes in Canada and global political economy since 1970. The Structural changes that resulted from a neoliberal transition had a negative effect on social housing. It ultimately leads to the off loading of responsibility from the federal government to municipalities and market forces. This although neoliberalism promised an increase in efficiency and greater freedom in individual choices, it never materialized in increasing social housing choices for low -income families.

Low-income families are particularly reliant on renting to fulfill their shelter needs, as such they have been adversely affected with the adoption of neoliberal ideas in the housing market despite promise to the contrary. Hutchinson (2004.) tells us that “a loosening of rent controls was predicted to induce the construction of affordable rental units in the private sector" (p.26). As we know this never materialized rent has been increasing steadily out of the reach of low-income families and the houses they can afford to rent are often dilapidated structures. 
What is even worse is that Neoliberalism is also credited for the destruction of secure good jobs and part-time employment are increasingly becoming the norm. It provides an opportunity for employers to keep workers on contract while saving on the cost to cover their health insurance and other benefits that comes with full time employment.

Nevertheless, there has been push back against the neoliberal agenda and recently in cities such as Toronto there was a 'Fight for 15 and fairness movement' (Ontario Federation of Labor, 2017). Many see this push back as creating an atmosphere of debate where workers voices are heard.

It is evident that neoliberal ideas will always play a part in housing, whether for low-income families or the general public now and in the future. There is a pervasive idea that the poor should assume some responsibility for their affairs and the idea that government should interfere with market forces seem reprehensible by many. Government responsibility should be limited to creating an environment that allows its citizen to prosper by their own efforts. This is evident in the housing policies in Toronto where government has assumed more of a regulatory role Municipalities which are most often cash strapped are now asked to be creative in developing plans to provide more affordable housing units.

the provincial governments. Initially there were three municipally owned and operated housing providers prior to 1997 before the city of Toronto was amalgamated. In 2002 the Toronto Community Housing Cooperation was born with a mandate to administer all public housing units within the new city. The city of Toronto is the sole shareholder of this entity and its legal power comes from the Ontario Housing Services Act 


\section{CHAPTER 3}

\section{Theoretical Framework}

I have chosen Governmentality as my theoretical framework. Between 1970 and 1984 Foucault was actively engaged in a series of lectures at College de France in Paris, towards the conclusion of these lectures Foucault introduced the concept of Governmentality. Li (2007) in referring to governmentality states that it can be “defined succinctly as the 'conduct of conduct', government is the attempt to shape human conduct by calculated means” (p.1). It is believed that when government attempts to regulate conduct it is done with a preconceived standard or norms of conduct in mind. Some ideal that which citizens should strive to reach and that it is possible to regulate conduct to reach this ideal state.

Many experts on Foucault believes that when he used the term governmentality, he was not just referring to political and the legislation that constituted the government, he was instead looking at it from a broader range. Rose (2000) believes he was "referring to the interactions or relations between political authorities and sites of power and influences within society, which include bureaucracies and institutions as well as families and communities”.

It is evident that when government attempts to control conduct it is presupposing that it has the moral authority to do so and whatever conduct it tries to regulate also lies within the ambit of its powers. According to Foucault (1991), the purpose of government is to secure the "welfare of the population, the improvement of its condition, the increase of its wealth, longevity, health, and et cetra” (p.100). If government is to take on such a comprehensive undertaking as suggested by its mandate, this will require certain craft and shrewd fashioning. It is suggested that the act of governing employs certain techniques and tactics in order for goals and objectives to be 
achieved. This is often referred to as the art of government. Governmentality comes into existence as a distinct activity of the art of government of the state which rationalises its exercise of power drawing on areas of knowledge of human and social sciences which become integral to it (Dean, 1999).

It is therefore evident that the craftiness and shrewdness of government is affected by the overarching political philosophy, which also influences what amount of power it can wield to achieve its goals. Importantly though is the idea that governmentality does not presuppose an ideal form of government but will generally ask "How is it that society comes to justify the control and regulation of the relationships and activities within the private sphere of society, including parenting?” (McHoul \& Grace, 1993; Rose, 2000, p.60).

Applying the lens of governmentality therefore provides us with a means to map how policy problems, such as family poverty have taken shape during the last twenty-five years in Canada under successive elected governments. What are the dominant discourses that inform poverty policies when a conservative government is in charge as against one with a liberal outlook. This exploration I believe will expose what many experts on governmentality would describe as the mentality ("mentalité") of government. In his speech and writing Foucault stresses the interdependence between the exercise of government (practices) and mentalities that underpin these practices.

Canada, commonly classified as a welfare state, has shifting mentalities towards social assistance programs, depending on which political party is in power. From a historical perspective, Social Democratic ideas predominated the state during the 1960, which lead to the expansion of welfare assistance programs. Adherents of Social Democracy believe that the 
expansion of welfare programs leads to a reduction in inequality. Moscovitch (2006) stated that this view has been expressed in platforms of the New Democratic Party (NDP) and its predecessor, the Cooperative Commonwealth Federation”. Canada as a whole seem to have shifted from the early ideology of the NDP if one is to judge it by its share of the popular vote in recent Canadian elections. It is now safe to say that Neo-liberal philosophy has been fully embraced by both the conservative and liberal party the two dominant political forces at present. According to Kronstein (2017) "nearly every provincial and federal government in Canada indeed, most governments in the western world - have adopted the ideology of neoliberalism in some form or another" (p.1). It is evident that socialist and social democratic parties in Canada have also incorporated neoliberal economic policies into their platforms.

As Mitchell Dean (1999) and others have pointed out, governmentality as a concept helps us to better understand how political ideology shapes the conduct of populations through the regulation or deregulation of markets. Neo-liberalism, which now seem to be a dominant force of political thought, can be understood as an economic doctrine that promotes participation in free markets as it stresses limited government dependency for one's economic needs. Under such a doctrine economic freedom becomes the panacea to improved social welfare, and noneconomic freedoms are expected to be aligned in the service of this social order. White (2002) tells us that "under a neo-liberal agenda many of the social programs have been de-centralized, downloading the responsibilities from the Federal Government to Provincial governments and often to the Municipal level as well”. Many scholars believe that the decentralizing of what was traditionally a central government responsibility now allows everyone to be implicated or tasked with finding solutions to these problems. 
Scholars of governmentality often looked at what the emergence and evolution of neoliberal regimes around the world have meant for social welfare services and its users. Full time employment for example is revered as the solution to get families out of poverty. In a neoliberal way of thinking the idea that the poor people should "pull themselves by their bootstrap" has resonated with many over the years (JF Switzer,2006). As such government policies and programs are geared towards finding that magical bootstrap such programs are generally geared towards increasing family incomes. Rose (2000), refers to neoliberalism as a rationality that views the welfare state as one that encourages dependency through handouts, which undermines both economy and society”. Many experts on governmentality therefore believe that one of the strength of governmentality is that it construes neo-liberalism not just as ideological rhetoric but as a political project that endeavors to create a social reality that already exists.

Even though government is described as the "conduct of conduct" it entails citizens who are free to act in ways that please them. Nevertheless, as Dean (1999) tells us that "government gives shape to freedom” (p.24). In this sense poor families are given limited choices or room to maneuver in terms of the dictates of policies that are created to help them. In one sense they are free to act but if they don't act in a prescribed manner they suffer the consequences and, in many cases, disqualify them selves from services. Many experts on governmentality therefore believe that government concerns the shaping of human conduct and acts to govern the free will of its citizens. The idea of the evolution of government has also been suggested by governmentality expert. Traditionally all power was concentrated in the hands of central government. According to Fimyar (2008) "nowadays what we find is more evolved into more decentralised and diffused (but not necessarily democratised) forms of power exercised by myriads of institutions and by the subjects themselves". This is certainly true when you look at social assistance programs 
which differs from province to province and rationales behind each program have different intended outcome and target groups. Another important point that should be noted is that with the Canadian government embracing a neoliberal agenda many now suggest that government nowadays can be classified as economic government. A situation that seem to be more pronounce during times of recession.

Finally, neoliberal governmentality, which is a form of post-welfare Canadian State politics will be used to provide a framework to view what is now believed as the "best" way of governing. The implication of this form of government on low-incomes families in Toronto who are seeking or living in social housing will also be investigated. Unearthing the dominant ideas that government hold of low-income families which justifies subsequent intrusions in their lives. 


\section{CHAPTER 4}

\section{Methodology}

This is a qualitative research study that will employ a Foucauldian Discourse Analysis to examine secondary data. The secondary data that will be examined are government policies and regulations relating to the management of social housing. As such I will spend some time looking at the Social Housing and Reform Act of 2000 that empowers municipalities to assume responsibility for social housing. It also spells out Service Managers role as landlord in social housing relationships. Policies of the City of Toronto as well as the Toronto Community Housing Corporation the second largest public housing provider in North America will also be examined. This research goes as far back as 1993, a turning point in political ideology surrounding welfare. As well as a period that saw the full-scale adoption of neoliberal policies in the provision of social housing.

In its simplest form Discourse analysis is concerned with the ways in which language constructs and mediate social and psychological reality. Some see this emphasis on linguistics as a major development in western thought to the point that it has become an all-encompassing framework for many. Foucault however, proposes a different way of doing Discourse Analysis. It should be pointed out from the onset that consensus exist that there are no strict rules or procedures to conduct a Foucauldian inspired analysis. Some attribute this to his views of discourse being more diffuse than linguistic approaches and his difficult style of writing. Foucault (1977) as quoted in Yates \& Hiles (2010) in attempting to provide some clarity to his work described it as "a series of inquiries constituting the histories of the present” (p.3). I believe the Foucault's approach is a better fit for a policy paper that seeks to look at the 'focal points of experience' over a historical period. Additionally, when referring to 'discourse', Foucault does not mean a particular instance 
of language use - a piece of text, an utterance or linguistic performance - but is keener on understanding rules, divisions and systems of a particular body of knowledge. As such a Foucauldian analysis is said to move from the superficial preoccupation with language and looks at techniques and practices through which objects, concepts, and strategies are formed which is generally done from a historical perspective

The relationship between Governmentality and Discourse assumes a commitment to be critical of Government and presents a way of examining government poverty reduction policies and social housing policies. It is believed that the concept of governmentality sheds light on the relations between discourses, the institutions and forms of text that discourses are embedded in, and the subject positions created through discourses (Gleiss 2015 p.40)

Discourses about social housing recipient cannot be detached from the States effort to govern low-income families in indirect ways. These new strategies of governance seek to make the poor responsible for their own welfare. Foucault introduced the concept of governmentality to characterize a new way of thinking about "how to be governed, by whom, to what extent, to what ends, and by what methods". Governmentality designates a specific way of exercising power that seeks to shape conduct. Discourse is therefore central to how governmental power is exercised as it is spelled out in policies and other governmental documents. Analyzing discourses from the perspective of governmentality theory also enables us to better grasp how discourses work politically. The discursive shift to Neo-liberalism facilitate the Canadian State project of downloading responsibility for social housing.

Although there is no prescribed way of conducting a Foucauldian analysis Walderton (2017. p3) has provided a useful framework for conducting such an analysis. The framework concentrates on "focal points of experience" which is done using three axes. Using this as my 
guideline I will look at the axis of knowledge -here the concentration will be on the rules that govern discursive practices. Rules for example that establish institutional bodies as the proper authority and spokespeople for the creation of an, object of discourse. As Walderton (2017) points out "rules that determine what is true or false". His premise is that systems of knowledge are governed by rules that determine the limits of thought and language within a given historical period (p.3).

The next axis is that of the axis of power. Power cannot be easily located in certain actors or institutions. Power creates knowledge and forms subjects who are restricted as well as enabled by its omnipresent force, Foucault (1979). In looking at power Baumgarten \& Ulrich (2011) states that "Foucault and others showed how knowledge and related practices are spread and maintained by "governmental" or "bio political" techniques of subjectification and especially through techniques of governing the self” (p.14). Given the historical dimension of Foucault's analysis I will look at how power/knowledge relations operate within the different political periods in Ontario. What have been the interventions that have been proposed for low-income families and the historical justification that has been given for those interventions.

The final stage of analysis will be concerned about axis of ethics (subjectivity). Hook (2007) believes that this domain "can be thought of as forms of subjectification that "involve the operation of a type of power that connects the norms of authorities to the motivating ideals we have of ourselves” (p246). Some writers see it as challenging to make subjectivity amenable to discourse analysis. Notwithstanding in my analysis I will be mainly looking at the aspect of subjectivity that is the ways low-income families are incited through power and knowledge and techniques of government to think of themselves as beings with certain rights, responsibilities, obligation, needs. Specifically, how they act upon themselves and shape their own lives and their 
own conduct and the rationalities according to which they do so. The study will seek to highlight the forms of knowledge which people draw on in viewing themselves as certain types (belonging to a certain group) and direct their conduct in this way. It should be noted that there is an interdependence and interrelation between the three axis that have been mentioned they; are not three separate analysis as aspect of one analysis affects the others.

Importantly, because the concept of policy is heavily debated and there is no general consensus on what it means. Even more importantly as Rolling (2008) argues, "policy does not exist in discrete units it is a part of a complex system without clear demarcations” (p.3). As such I will adopt the definition of Salisbury (1995) where he states that 'policy is the authoritative allocation of values for the whole society a general frame of authoritative rules” (p.34). It was further mentioned that policy is political behavior which is goal oriented. It would be very exhaustive to examine all the policies that have been created historically and in recent times to ameliorate family poverty. My analysis will focus on the Toronto housing system that will include the social housing market and housing policies that have been implemented to address the issue of the quality and inadequacy of housing. Subramaniam (2018) citing data from the Canadian Rental Housing Index revealed that "almost half of all renters spend more than 30\%of their income on rent”. I therefore see this large income transfer for housing inevitably affecting family poverty. In my approach I will employ a thematic policy analysis which will allow me to capture the dominant themes in the secondary data reviewed. According to Mayring et at as quoted by Vasmordi (2013) "It is a systematic coding and categorizing approach used for exploring large amounts of textual information unobtrusively to determine trends and patterns of words used, their frequency, their relationships, and the structures and discourses of communication” My aim is to search for and identification of common threads across the data set. My coding and theme 
development will be directed by the content of the data. The coding that I will embark on will involve generating succinct labels that identify important features of the data. It will also provide some clarity to my research question. I will code the entire dataset, and after that collating all the codes for the later stage of analysis.

The next phase that I will embark on will involve examining the codes and collating data to identify significant broader patterns of meaning (potential themes). Here I will be collating the data relevant to each theme, so that I can work with the data and review the viability of each theme. I am also mindful of the instructions that are given by Maxwell (2005) who states, "To design a (qualitative) study ... you can’t just develop ... a logical strategy in advance and then implement it faithfully". It is an ongoing process that involves "tacking" back and forth between the different components of the design., assessing the implication of goals, theories, research questions, methods and validity threats for one another. As such, I will review the initial themes that arises for reviewing social housing legislation, Ontario government housing policies and checking these themes to determine if they tell a convincing story.

As Dean (2010) puts it, “An analytics of government examines the conditions under which regimes of practices come into being, are maintained and are transformed”. The regimes of practice that will be of importance are those that relates to poverty reduction. It is believed that although the different regimes that operate to reduce poverty operate with distinctive mandates they nevertheless link up to form a housing system. These systems are then informed shaped or reshaped by a certain kind of knowledge. Gordon and Foucault as quoted in Dean (2010) states that "Regimes of practices are associated with and become the objects of define, explicit programs” (p.19). 
Through the mid-1990s, neoliberalism became a persuasive policy discourse in liberal democracies such as Canada (Carroll \& Shaw 2001). Canadian social assistance programs must be understood through the lens of the overarching macro-economic framework and ideology o will lean on for my analysis. In the subsequent chapter. I will outline some of the dominant teams that arise from the documents that were examined. 


\section{CHAPTER 5}

\section{Findings}

Devolution/ Amalgamation:

This chapter will outline the themes that came to the fore after following the dictates of the Methodology that was outlined above.

Devolution is a process in which a central level of government offloads or delegates particular responsibility to a lower level of government, (Weaver and Habibov, 2010). The offloading of responsibility for social housing has real consequences for lower level of government. As in the case of Ontario, it was accompanied by a reduction in the amount of money that Central government provided (see fig 1). Lower level government as a result are burdened with increase financial responsibilities. The provincial government first announced the devolution of social housing in January of 1997 as part of the Local Services Realignment. As such, the province of Ontario designated 47 Consolidated Municipal Service Managers (CMSM) to take charge (Social Housing Services Cooperation 2008).

The Social Housing Reform Act, 2000 is the legislation that became law on December 14, 2000, which enable the transfer of administrative responsibility for social housing to the municipal level. The legislation requires that the CMSM take over administrative responsibility for social housing within their defined geographical area and to take ownership and management of the OHC public housing stock. (The Ontario Professional Planners institute 2001). It is Section 5 subsection 1 that's gives power to Service Managers. The legislation gives us a clear idea as to where power resides in social housing. Power as we know is central to governmentality and in 
this sense, it shows us who is empowered to regulate conduct and who decides who gets what.

The Act states as follow.

\section{Powers of service manager}

5. (1) A service manager may,

(a) Purchase or otherwise acquire a housing project in its service area for the purpose of operating it as a housing project;

(b) Purchase or otherwise acquire land in its service area for the purpose of operating a housing project on it;

(c) Construct a housing project on land that it has acquired in its service area

(d) Make alterations or additions to a housing project that it has acquired or constructed in its service area

(e) Operate and maintain a housing project that it has acquired or constructed in its service area

(f) Sell or otherwise dispose of land and housing projects that it has acquired or constructed in its service area

(g) Exercise such other powers as may be prescribed. 2000, c. 27, s. 5 (1).

\section{Power to establish programs}

(2) A service manager may also establish, fund and administer programs for the provision of residential accommodation in its service area. 2000, c. 27, s. 5 (2).

Service Managers play a critical role in ensuring that Toronto has adequate social housing unit it is however debatable if they are equipped to take control of Ontario's social housing stock given federal cuts. Federal housing expenditures were restricted to about $\$ 2$ billion annually between 1995 and 1997 (Fallis, 2010). During this same period, the province limited its funding to $\$ 42$ million annually with $\$ 215$ million directed towards one-time capital upgrades to existing housing (Graham \& Phillips, 1998), these drastic cuts represented a decrease of almost $\$ 700$ million from la peak of 4.1 billion in 1993. In both cases, there was no direct spending for the creation of new affordable rental units. Rather, these funds were meant to maintain the existing affordable rental stock. This lack of funding has resulted in a drastic drop in the production of affordable rental units, averaging out to some 1000 units being built annually between 1996 and 
2001. This represented a significant decrease from the late 1970s and early 1980s of 20,000 units yearly (Shapcott, 2007). The figure below shows what federal spending on social housing has and will look like until 2029 before the propose phase out of spending.

Figure 1: Withdrawal of federal funding for social housing in the City of Toronto, 2001-2029

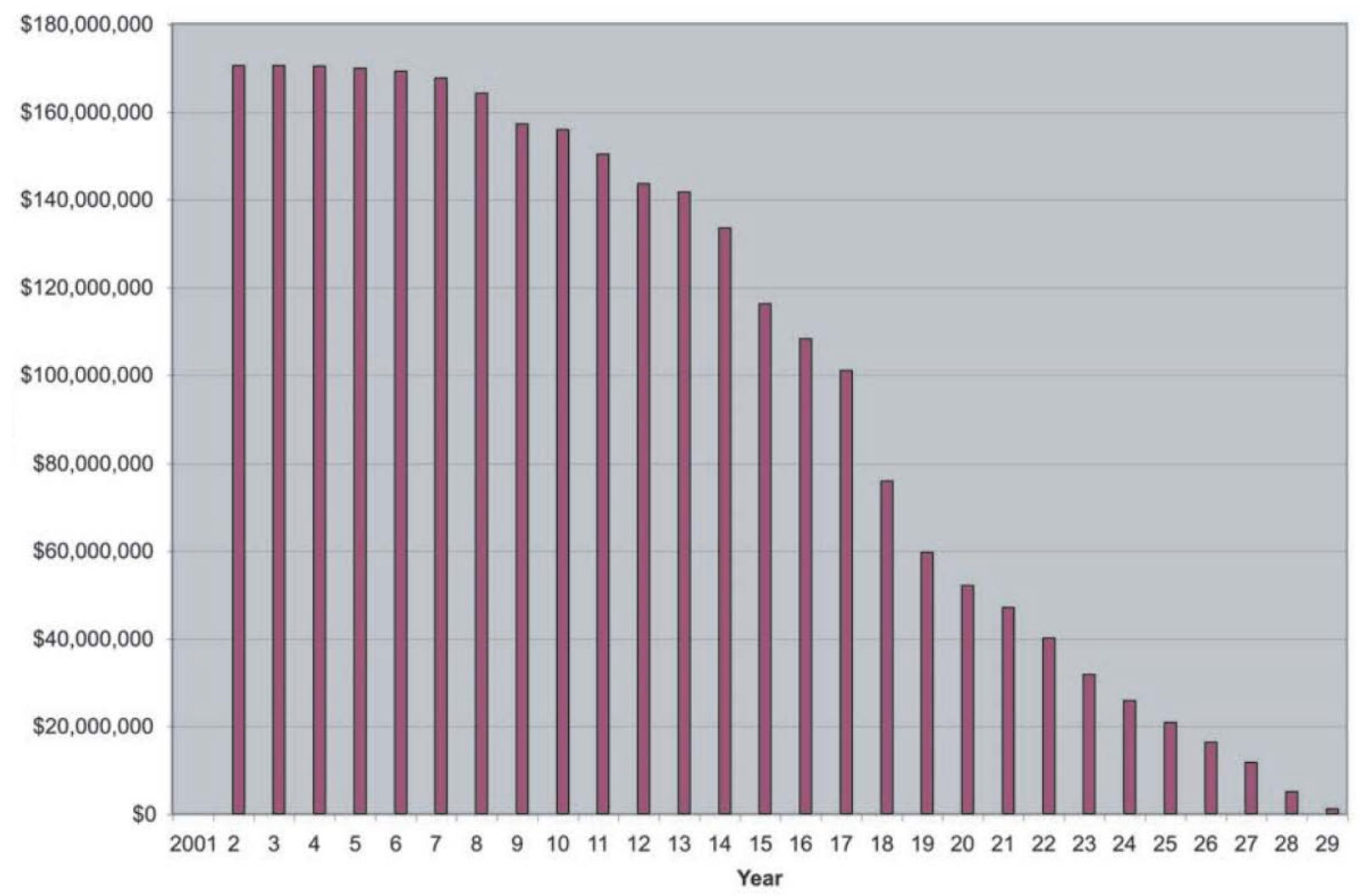

Source: City of Toronto, 2007

As illustrated in Figure 1, funding has begun to decline steadily until a rapid decline took pace from 2008.Additionaaly source of funding will have to be sought to make up for declines. For example, in 2008, the city lost $\$ 570,000$ in federal funding, and in 2009, it lost a further $\$ 1,082,405$ (City of Toronto, 2007). These cuts are a result of the federal government electing not to reinvest funds from expiring federal social housing agreements back into social housing 
(City of Toronto, 2007). In Toronto, the effects of devolution were further compounded with the provincial election of Mike Harris under the Common-Sense Revolution manifesto in 1995.

One of Harris's main platforms was to reduce the overlap and duplication within and between governments - much like that of the federal government. This led to the divestment and disengagement of the provincial government from the governing and financing of social housing (Graham \& Phillips, 1998). Mike Harris campaign platform was centered on a twenty-one-page document called the 'Common-Sense Revolution' which sets out his plan for the province. A section of this document titled Reform Welfare states as follow:

We want to open up new opportunities and restore hope for people by breaking the cycle of dependency. That will be the goal of our welfare program. The best social assistance ever created was a real job, and this plan will generate hundreds of thousands of those. (Common Sense Revolution., 1994)

A former Harris cabinet minister, John Snoblen, wrote as quoted in the Toronto Sun stated:

"Lesson one from the Harris days is to cut deep, quickly.” (Toronto Sun). The central idea being when government is lean it becomes more efficient. Social assistance in particular was now seen as a drag on public finances a burden the Government is no longer willing to accommodate. In line with the idea of 'cut deep 'the Progressive Conservative introduced Bill 103:

The Bill replaces the seven existing municipal governments of Metropolitan Toronto with a new single-tier City of Toronto. The new city, which comes into existence on January 1, 1998, will be divided into 44 wards. The first city council, consisting of one member elected by each ward and a head of council elected by general vote, will be chosen in the 1997 regular election and will take office at the start of 1998. (City of Toronto 1997)

The megacity idea had dissenting voices, who rejected the idea of amalgamation, in a held municipal referendum in 1997.In fact those who oppose amalgamation greatly outnumbered those who did not in the held referendum. Those municipalities that oppose were said to have a win-win arrangement with the Regional Municipality of Metropolitan Toronto (RMMT). Where 
the RMMT was responsible for their social services, while local councils only dealt with city government issues. It then became easy to frame those who oppose amalgamation as unindustrious, who were a drag on the Regional Municipality purse and wanted to remain that way. As Minister of Municipal Affairs at the time, Al Leach confirmed "The city will be leaner than the old one: the government project cost savings of $\$ 864$ Million by 2000" (Canadian Encyclopedia 2013). In an economic discourse cost are present as an economic and social liability. The savings that will be achieved by amalgamation becomes a sensible option that is justified by future savings. It then became easy to off load social housing to municipalities and the Social Housing and Reform Act (SHRA) of 2000 came as a result.

We can see a change in the discourse surrounding persons who seek social assistance in the policies of Ontario. No longer are social assistance receipts seen as passive in the political welfare vocabulary. There is the problematization of the issue of dependency. Ayllon \& Valerie Walkerdine (2017) tells us “The discourse of dependency has a long history, extending as far back as feudal bondage, which undergoes significant transformation in the early nineteenth and late twentieth centuries”. From a Foucauldian perspective ‘welfare dependency' helps us to construct a genealogy of contemporary welfare rationalities and we can then explore the effects of welfare reform on self-formation. Gaining employment in a "real job" is now seen as part of self-actualization. The job seekers and those who are unemployed are demoralized by the Common-Sense Revolution and will undergo continuous monitoring and are expected to ethically reconstruct the self.

The problem of dependency as it appears as such in the Common-Sense Revolution policy proposals is made explicit through its proposed solutions. In other words, proposed actions indicate what Government thinks must be changed through the use of policies. Here in a 
neoliberal context work is seen as the solution to dependency. Government then sets out to create an environment where there is full or near full employment. Government has now devolved itself from the responsibility of taking care of the wellbeing of its citizen as Askhiem et al states "The democracy/rights discourse springs from the right of individuals to control their own lives, as full citizens in society”. As it pertains to housing as a welfare program:

The Harris government terminated Ontario's affordable housing programs and dumped the cost of running provincial social housing onto municipalities. The result has been a rising rate of homelessness, a growing social housing waiting list, and a maintenance and repair backlog in a crumbling social housing stock that numbers in the billions of dollars (Canadian Centre for policy Alternative 2015).

The Common-Sense Revolution (CSR) must have resonated with a significant portion of the voting public as Harris won the 1995 election. The anti-social housing plan that emanated from the government did little to change public perception of those who seek and live in public housing but instead further the stigmatization. To date Toronto is still suffering the after effects of Devolution as Service Managers are finding it hard to fully fund social housing projects.

\section{Revitalization /Mixed Income Development}

The term revitalization began to appear in literature in Canada around the 1930s. Disagreement exist as to how to define and achieve mixed use but there is some consensus that mixed used involve "the co-location or immediate proximity of homes, workplaces and services in buildings, neighborhoods and districts” (Hirt, 2016, p. 134). Mixed use policies are generally implemented through zoning codes. Roberts and Sykes (2000) are of the view that "Urban renewal in Canada and the United States focused on run-down residential neighborhoods in cities; renewal programs centered on physical change in urban arears” (p.18). From a Toronto perspective the revitalization of large housing projects was said to be the most prominent housing project 
undertaken within Toronto by municipalities. Revitalization became necessary as cuts during the Harris era coupled with Devolution resulted in few housing units being built and existing ones were in a state of disrepair. The province subsequently developed policies to facilitate mixed housing.

Provincial Policy Statement, 1996 (PPS). The section of the PPS dealing with housing states:

Provision will be made in all planning jurisdictions for a full range of housing types and densities to meet projected demographic and market requirements of current and future resident of housing market areas by:

Maintaining at all times at least a 10-year supply of land designated and available for new residential development and residential intensification;

Maintaining at all times, where new development is to occur, at least a 3-year supply of residential units with servicing capacity in draft approved or registered plans;

Encouraging house forms and densities designed to be affordable to moderate and lower income households;

It is clear from policy statement that the private sector or contracting company have the upper hand. The Policy states that municipalities will encourage affordable to moderate and lower income household. It is difficult to see Municipalities encouraging private investors to try to minimize profits by appealing to some moral responsibility to help low-income families. It is more practical that private investors who in some cases have to account to shareholders are trying to build units that maximize profits for their companies. In furtherance to the idea of private/public partnership the TCHC has the following on its webpage:

By working together with the City of Toronto, our residents, our neighbors, and our private development partners, we are transforming aging housing infrastructure to build better homes, better neighborhoods, and a better Toronto for all. Revitalization is creating vibrant communities with increased opportunities. It attracts investment in the form of new or improved amenities like schools, parks and community facilities. It also provides job and 
training opportunities for residents and creates opportunities for affordable home ownership. (Toronto Community Housing ,2011)

The provincial government is not only encouraged deregulation but is actively encouraging housing providers to be entrepreneurial and function like the private housing market. It is difficult to analyze the idea of building "better neighborhoods" as stated in the aforementioned statements. Nevertheless, the idea of socially mixed housing has always been a part of any revitalization effort. Fraser and Kick, (2007) points out that "In addition to purported social benefits the development of mixed neighborhoods is viewed as an opportunity to achieve placebased goals such as revitalizing the built environment and securing new commercial investments”. The rational social mixed housing that includes a range of tenure types and income level, is the idea that high concentration of poverty contributes to social and economic isolation of residents. In such a script low-income resident will have positive behavior change through modelling the behaviors of persons from a higher socio-economic status. In essence Municipalities were attempting to transform poor residence through what Foucault $(1985,1997 a)$ called technologies of "power and self" by inviting them to assume a certain subject position. Conduct was governed from a distance through government policy and legislation that facilitated the creation of mix-communities. One such policy was The Large Sites Policy.

This policy requires that new residential sites over 5 ha provide 30\% of the housing in attached and multiple housing forms, and projects seeking increases in height and density provide $20 \%$ of the additional residential units as affordable housing. (City of Toronto, 2006, s.3.2.1.9 (b))

The Large Sites Policy fell within section 37 of the Planning Act and allowed developers to breach the city development by-laws to facilitate certain types of housing development. According to Shapcott, (2004) “The Ontario government tried to sell its private-sector 
mantra by dressing up the old "trickle-down" theory in new clothing. A theory that claims benefit to the wealthy will trickle down to everyone else. Neoliberalism has always promised a more efficient way of conducting business. With emphasis on freedom of individual choice, nevertheless it is generally agreed that the changes in the structuring of social housing in Toronto have not been beneficial. The figure below shows the effect of governments effort at mixed housing approach.

Fig 2. Relative cost per room of housing in the city of Toronto's (Canada) mixed-use zones

\begin{tabular}{|c|c|c|c|c|c|c|c|c|}
\hline \multirow{2}{*}{ Area } & \multicolumn{4}{|c|}{$\begin{array}{l}\text { Households paying more than } 30 \% \text { of } \\
\text { income on housing }\end{array}$} & \multicolumn{4}{|c|}{$\begin{array}{l}\text { Average housing costs as a percentage } \\
\text { of average individual income }\end{array}$} \\
\hline & \multicolumn{2}{|c|}{ Own } & \multicolumn{2}{|c|}{ Rent } & \multicolumn{2}{|c|}{ Own } & \multicolumn{2}{|c|}{ Rent } \\
\hline Mixed-use zones in the city of Toronto & $29 \%$ & $32 \%$ & $43 \%$ & $47 \%$ & $42 \%$ & $35 \%$ & $31 \%$ & $24 \%$ \\
\hline Rest of the city of Toronto & $22 \%$ & $25 \%$ & $42 \%$ & $45 \%$ & $40 \%$ & $34 \%$ & $27 \%$ & $21 \%$ \\
\hline
\end{tabular}

Statistic Canada 2006

The data above, compares the first two metrics for both owner and tenant households in mixeduse zones with other areas of the city in 1996 and 2006. The results show that housing in Toronto was generally least affordable in mixed-use zones. Fig 2 shows that the proportion of households spending more than 30\% of income on housing increased between 1996 and 2006 in mixed-use zones and other areas of the city; however, this increase was greater in mixed-use zones for both those who owned and those who rented. The results may be what Hulcganski (2010) has been saying that most development most new developments in downtown Toronto, many of which are located in mixed-use zones, have been condominium developments, with few rental units developed. 
The other technology that was employed by the Toronto municipality was that of selfregulation. Low-income families were expected to engage in self-regulation as a result of living next door to persons who were more affluent (modelling). This was particularly evident in the proposed rebranding of Jane and Finch a community that has been tainted in the public imaginary and considered to be one of the most dangerous place in the city.

As such municipalities were engaged in ethical problematization since the idea is to transform low-income residence by getting them to behave a certain way. Government on one hand by pushing a revitalization strategy that the concentration of low-income families in a particular geographic area is a burden to the city as it stifles the competitiveness of the city. Government through Transformation then takes on a mental element and the practical work involves submitting oneself to a set of moral recommendations or obligations. The rebranding of Jane and Finch would involve a change of name to University Heights a subtle message meant to highlight the University that was close to the area. Another "gift box" was a stop on a \$3billion dollar subway line and an \$880 million LRT line. Rebranding Jane and Finch to University Heights validates the stigma that is in existence and suggest that a top down approach steeped in neoliberalism can solve community issues. In looking back from the early periods of the Harrison era, we can see a rebranding of the discourse surrounding low -income residents. The early periods were marked by isolating individuals in discourse, based on identifiable markers (dependency, employment, remaining off social assistance.). The encouragement of restructuring of behaviors to produce 'responsible citizens'. The lexical choices in policies was consistent with this discourse. At the revitalization stage, the argument has change and public expenditures are described as an investment in the future well-being of the society. As Carrier and Lower (2017, p.109) tells us "Removing individuals from poverty is equated with a monetary return”. It is also 
interesting to note that there was a purposive use of, revitalization, rebuilding, mixed income development in official Government documents.

It therefore seems like the promise of improved economic opportunities that were promised to low-income families as a result of revitalization did not materialize. In practice, what occurred was that low-income families were removed from their homes. Additionally, there is no evidence to suggest that low-income families that remained in gentrified communities developed any social bonds with their richer neighbors. What occurred was that there was very little substantive mixing or interaction between community members of different socio-economic backgrounds. Writers such as Joseph et al., (2007) suggest, “old residents participate unevenly in social and civic activities, and their interactions in these activities are generally not substantive enough to generate significant outcomes”. As such mixed income housing does not generally lead to a mixed income neighborhood or general intermixing of different social groups for that matter. It should be noted that Jane and Finch was just one of several community in Toronto that was slated for revitalization during this period. The general ethos that accompanies revitalization projects was evident in all the other communities that were marked for change. 
Pics of revitalization taken from Toronto Community Housing archives.

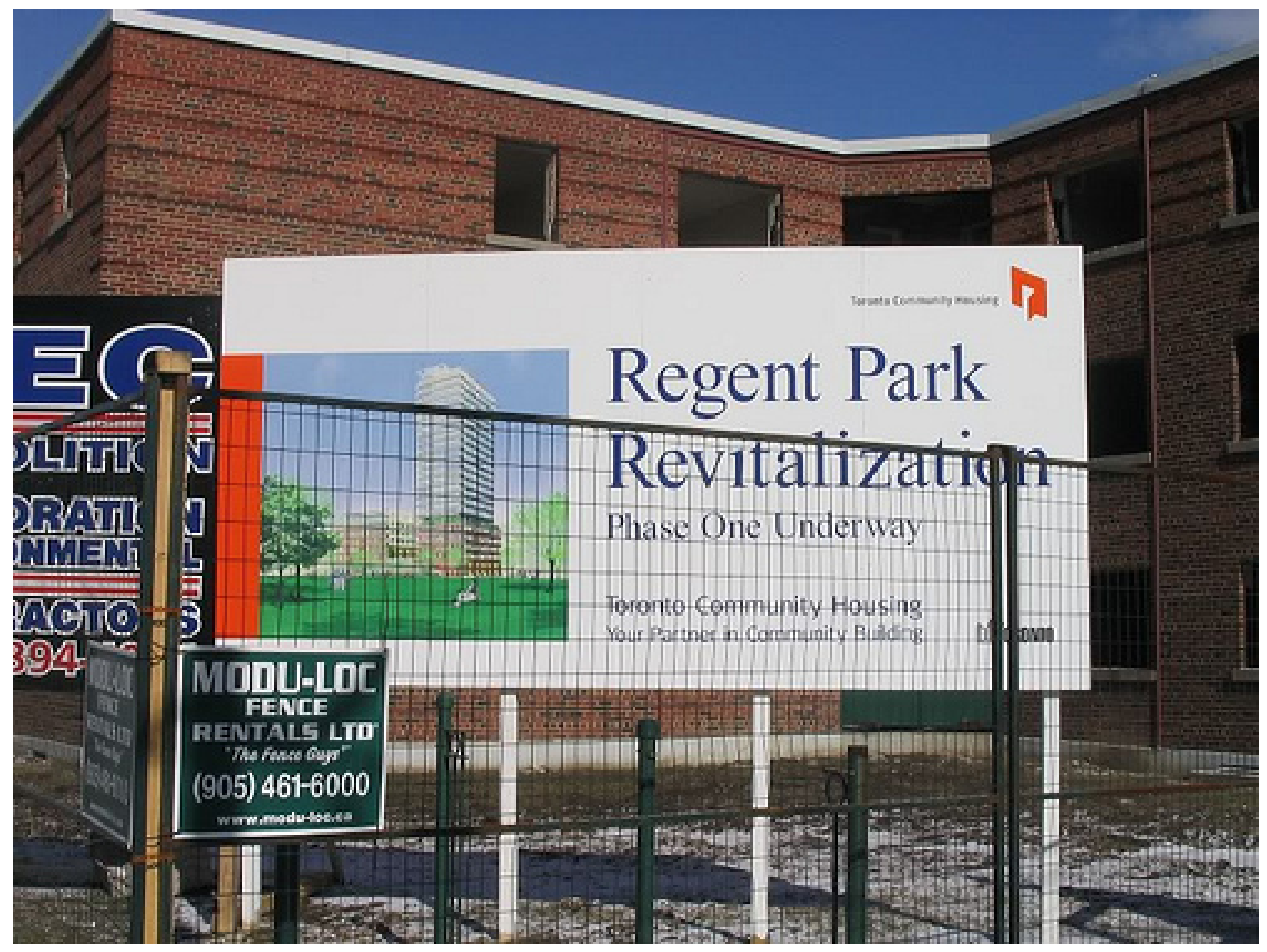

\section{$\underline{\text { Rent /Homelessness }}$}

As stated in before home ownership is out of the reach of most low-income families and renting becomes the only option to prevent being homelessness. This theme therefore looks at this final avenue that is available before families are cast on the streets. It is important to point out that this research paper is not about homelessness. The issue of Homelessness is far too complex to unravel in such a short research paper. This theme explores the policies /legislative support that are available to renters as a final choice before they lose that stable abode. I will look at policies 
related to renting from government and on the open market. The final section will touch a little on laws relating to persons who are unable to secure accommodation (homeless)

Policy Statement on rent:

Toronto Community Housing is committed to keeping evictions for not paying rent to a minimum. Toronto Community Housing will work with tenants and external supports or service agencies where possible, to keep tenants housed and to ensure that rent is paid, and eviction is the very last resort. The policy is established within the context of the Shareholder Direction from the City of Toronto, the Housing Services Act, 2012 and the Residential Tenancies Act 2006. (TCHC 2018)

It is difficult to know what the TCHC means by "where possible" in its policy statement, equally difficult to operationalize is the concept of "very last resort". It however suggests that evictions and very last resorts are at the discretions of Service Managers or its delegates. What is evident however, is that the TCHC does keep surveillance on its tenants in determining who gets what and also who gets to remain on its premises. As it punishes low-income families who manage to secure high paying jobs after living in social housing units and those who are classified as over housed. This is reflected in the agencies over-housed and income policy that states:

If you are living in a unit that is too large for your household as outlined in the City of Toronto's OccupancyStandards, you will be added to Toronto Community Housing's internal transfer waiting list. Staff will work with you to find a unit that is the right size for your household.

Section 8 of O.Reg. 298/01 sets out rules for local income and asset limits. If an income limit is established, a household's total income (total of all payments of any nature paid to each member of the household for a 12-month period) is compared to the income limit. If their income is over that limit, then the household would be ineligible to receive rentgeared-to-income assistance

(TCHC 2018)

It seems that it is older residents that rent from the TCHC that are targeted more than any group for eviction. In May 2009, 81-year-old TCHC tenant Al Gosling was evicted for rent arrears, he 
lost his subsidy because he did not submit paper work regarding his income (Justice Lesage Report 2014). Sadly, Al who became homeless, died five months after his eviction, this prompted an investigation by the housing Ombudsman. The report found the following: I found that TCHC's policies, guidelines and practices to prevent eviction, were not being followed consistently. While policy dictates that eviction was to be a last resort that was sometimes not the case. Early intervention was not occurring sufficiently, and TCHC relied on a high volume of dense and sometimes threatening correspondence, rather than in-person contact

(Report to Toronto City Council on TCHC 2014)

What we see is the silencing of the voices of older residence. It then reinforces the notion that older residence are not worthy citizens or tenants. People who become homeless like AL are viewed as having individual disturbances or disorders. It then becomes easy to evict residence who are deemed "less than", rather than addressing the barriers that older residence face in completing required paperwork.

The lack of investment in affordable housing combined with a severely reduced social safety led many families to become de-housed. The choice(s)presented are few for many, the open rental market is filled with Landlords who play the supply game effectively. With Toronto experiencing a perpetual supply crunch it will be a Landlord paradise for some time.

If we look at persons in social housing units as complete beings; in need of food and other basic needs. Then one has to look at data from Statistics Canada to gain a broader picture over a historical period "consumer price index, the dollar experienced an average inflation rate of 2.04\% per year. Prices in 2003 are 17.54\% higher than prices in 1995” (Statistic Canada2006). Therefore, a three-percentage increase in social and shelter assistance does little and shows no real commitment on the part of government to tackle poverty or homelessness. It was said that 
the rates of assistance are so low that recipients often have to choose between buying food and paying the rent.

The liberal government of Ontario from 2003 onwards continued to push a partnership strategy with the private sectors and communities. Fast forward to 2018 and very little has changed in making housing affordable in Toronto. The proposed development for 2019 in Reagent Park by TCHC tells the story about where rental cost are heading. for the units at 110 River St.

To qualify for an affordable rental unit, an applicant's household annual gross income cannot exceed four times the annual rent of the unit they are applying for. Please see the table below for Income limit:

Fig 3.

\begin{tabular}{|c|c|c|c|}
\hline Bedroom Size & Monthly rent (utilities included) & $\begin{array}{l}\text { Minimum gross } \\
\text { household } \\
\text { income } \\
\text { per year }\end{array}$ & $\begin{array}{l}\text { Maximum } \\
\text { gross } \\
\text { household } \\
\text { income } \\
\text { limit per } \\
\text { year }\end{array}$ \\
\hline 1 bedroom & $\$ 962$ & $\$ 11,544$ & $\$ 46,176$ \\
\hline 2 bedroom & $\$ 1,141$ & $\$ 13,692$ & $\$ 54,768$ \\
\hline 3 bedroom & $\$ 1,358$ & $\$ 16,296$ & $\$ 65,184$ \\
\hline
\end{tabular}

(TCHC2018)

In analyzing the proposed rental cost for Regent Park, a low-income community, we have to take the following into account. In 2015 there were 543,390 persons or $20 \%$ of the population had an income below the Low-income measure after tax (LIM-AT). In Toronto, males had a median total individual income of \$33,456 and females had a median total individual income of \$27,576. (Statistic Canada 2016, Census: Income). This works out to a monthly salary of 2,788 for the average male and 2,298 for the average female to live on monthly. We are provide with a graphic picture of how hard it will be to survive paying the proposed rents, if you subtract cost of rent 
from monthly salary. Low-income families will have to be creative to survive and outside of sheer luck it is difficult to see younger families saving enough to purchase a home in such a tight squeeze. The situation is even dimmer for retired persons and will become more vulnerable for homelessness as they often live on a fixed income.

In essence, it is unlikely that a change will be occur in present neoliberal script of the reliance on the private market to take care of vulnerable citizens. There seem to be no going back to the ideology of the interventionist post world war generous welfare state policies. Irrespective of political leanings, the common discourse will still be the same; the poor should pull themselves up from their 'bootstrap'. 


\section{CHAPTER 6}

\section{Analysis/Discussion}

Based on the historical patterns of Federal funding since the post -world war era. There is consensus in the Literature and from government policies examined, that limited allocation to welfare will be the new normal. It is difficult to see a future where the Canadian government, irrespective of political ideology abandon its neoliberal leanings. Governments seem to be more concerned about economic imperatives than having an adequate safety net for its most vulnerable citizens.

In the provision of affordable housing, it is difficult to see it going back to the responsibility of the federal government. Toronto, which is the most populous municipality, does not have the means to build more social housing. Even with the partnership of the private sector, there have been limited success. In any event, the cost of buying a home is out of the reach of most lowincome families and a better way to assist them would be through a comprehensive system of rental assistance. At this point it may be the only form of safety net than can be provided to persons who are spending more than thirty percent of their income on paying rent.

Another interesting finding relates to the fact that much like other North American cities, nonprofit housing providers including the TCHC, have been found to rely on private sector involvement. In the case of the TCHC, they are heavily reliant on private sector involvement, particularly during the construction phases (TCHC, 2011). Rather, it is an expected outcome as the post-welfare state has been heavily influenced by the shifts in economic and political culture during the 1990s. It does, after all, represent the "roll out" phase of the neoliberalism. These were premised on dismantling the welfare state gains of the 1970s, thereby reducing the size of 
governments and liberalising the markets. Much of the literature surveyed have suggested that these policies, particularly with regards to the CSR movement, have led to the marketisation of many social services such as affordable housing (Hackworth \& Moriah, 2006; Kipfer and Keil, 2002; Keil, 2002).

\section{Implication for social work}

It is safe to say that social workers engage with poor families living in low-income and subsidize housing more than any other profession. Social Workers unlike other professionals get to see firsthand the effects of poverty on low-income families. Nevertheless, the voices of social workers are notable absent from discussions around public housing policies and are mainly left to economics and other Government technocrats. Despite the clear effects that precarious housing arrangements has on family poverty and the wider implications of poverty.

It is common in our practice to listen to people's stories which are often filled with despair and struggles. Intersperse with these stories are stories of resilience from families who use creative strategies to overcome dire challenges and are now thriving. Testimonies of resiliency should not be forgotten, while are we busy filling work quotas and trying to be efficient and accountable to our various departments. Documenting and sharing these stories of resistance to others who are now in similar situations and to those can change policies should become part of our duty as well.

By deflecting the neo-liberal descriptor of low income families as someone who is not selfsufficient and is somehow deficit, Social workers can help low-income families build a new story. As an example, a 'job seeker' narrative can be used for persons who are actively seeking 
work as against the descriptor of unemployed which suggest a final state of affair. Social workers have a duty to help fight back against the stigma that their client face and by changing the language people will cause some reflection on their part. The not in my back-yard attitude towards social housing that may harbor is a culmination of the pervasive stigma that must be address.

Of importance is the fact that social workers are highly educated, their credentials are valued in a neo-liberal market place. It gives social workers a voice, they can communicate in the language of decision makers who will give them a listening ear. The voices of the marginalized poor are purposely silence both in the media and official documents it is simply not valued. Advocating for a space and voice for low-income families now must take a central place in the work we do. In all this one must be cognizant of the overarching neoliberal agenda which affects how the practice of social work is configured. As Johnstone et al. (2017) tells us "Social work expertise is distilled to concrete task-oriented service provision, and the pressing need for a sophisticated multidisciplinary systemic approach to social problems is blurred”. The result we are told is a diminished commitment to social justice and social equity. The profession has lost its way unwittingly, especially in some practice settings. Social workers particularly in child welfare settings have historically shown an eagerness to remove children living with low-income communities than those living in upscale neighborhoods. The sculpting of low-income parents as poor parents goes beyond child protection it affects how they are seen and thus their ability to secure rental apartments. The profession is therefore implicated in reinforcing and perpetuating stigmas about low-income families.

It is important that Social workers bring to the public discussions the structural causes of poverty and lead the discourse away from individual culpability. In all this what has been forgotten by 
social workers and policy makers is that poverty is bad for families. Toronto as the city has too many communities where families are struggling to keep a roof over their heads. The problem is therefore one of a lack of affordable housing rather that any perceived pathology that homeless people are said to suffer from.

This new approach will resonate will more persons who can identify with and remember a time when they too struggled. With devolution, municipalities often complain about budgetary constraints. Social problems including homelessness cannot be solved by a profit-based private sector, it should be part of the collective caring responsibilities of communities. It must be a significant permanent part of budgetary allocation.

Therefore, social workers need to challenge the dominant neoliberal oppressive discourse of minimizing the provision of social service delivery. Welfare spending does not necessarily lead to a weak economy, when more persons participate in the economy it can only become stronger. 


\section{CHAPTER 7}

\section{Conclusion}

This paper has attempted to explore the popular discourses surrounding low-income Torontonians who struggle to afford adequate housing. This is done against the backdrop of devolution which was the prominent theme during the 1990s.From the research it is apparent that one of the most significant change witnessed is the change in thinking from an earlier Keynesian post-war environment, to a neoliberal inspired policy environment. Which has affected the ideas around social assistance and housing in general.

A change in policy direction has been credited as the main reason why low-income families are de-housed at an alarming rate. Toronto remains a divided city with unequal opportunities and living conditions for families. Low income earners cannot secure housing that is adequate or affordable. The city's housing landscape has become segregated with low-income families generally living in subsidize run down high-rise buildings.

There have been attempts at revitalization (social mix type solutions. The evidence nevertheless suggests that "social-mix" becomes an attempt to gentrify low-income neighborhoods. And upon completion of these developments poor families are generally pushed out as they cannot afford the hike in rentals that generally results. Revitalization ventures have an economic underpinning they are design to make Toronto a more competitive global city and to attract further investment from private capital. They do little address the situation of those most needy despite the promises that they come with.

It is an acceptable fact that neoliberalism ideas will be a persuasive factor with governments now and future. In fact, each of the discourse discussed points to neo-liberalization ideas as underpinning the structures and conditions that perpetuate and sustain poverty. Yet somehow 
low-income families are made culpable for the systemic failures that accompany neoliberal restructuring.

There is a role to be played by the private market to construct affordable housing units either through subsidization or bonus. Nevertheless, Government which seeks to regulate conduct must find the right mix of legislation to regulate the exuberant entrepreneurial spirit that is running wild in the Toronto housing market. The remedy for poverty is likely found when everyone in Toronto can afford a place to live.

Toronto motto is "Diversity Our Strength" in supporting this diversity we must ensure that affordable housing is reality for all. As such we must be aware of groups that are left behind historically make commitments to give them a voice. They should be involved in planning decisions that will affect their lives.

Unaffordable housing perpetuates poverty and there is well established evidence to show the effects of poverty on families especially children. One of the corollary of poverty, homelessness is reaching crisis proportion. Sadly, the voices of the homeless is mainly heard during times of winter when they are freezing to death on our streets. The problem of homelessness might be a complex issue and perhaps no single strategy will be successful, but solutions will be effective when all are involved in finding solutions. 


\section{REFERENCES}

Bárcena-Martín, E., \& Pérez-Moreno, S. (2017;2016;). Immigrant-native gap in poverty: A cross-national European perspective. Review of Economics of the Household, 15(4), 1105-1136.

Beaulieu, N., Duclos, J., Fortin, B., \& Rouleau, M. (2005). Intergenerational reliance on social assistance: Evidence from Canada. Journal of Population Economics, 18(3), 539-562.

Borjas, G. J. (2011). Poverty and program participation among immigrant children. The Future of Children,

Brail, S., \& Kumar, N. (2017). Community leadership and engagement after the mix: The transformation of Toronto's regent park. Urban Studies, 54(16), 3772-3788.

Canadian Journal of Communication Vol 36 (2011) 619-635 2011 Canadian Journal of Communication Corporation

Chaudry, A., \& Wimer, C. (2016). Poverty is not just an indicator: The relationship between income, poverty, and child well-being. Academic Pediatrics, 16(3), S23-S29.

Crossley, T. F., \& Curtis, L. J. (2006). Child poverty in Canada Review of Income and Wealth, 52(2), 237-260.

Curtis, L. J., \& Pennock, M. (2006). Social assistance, lone parents and health: What do we know, where do we go? Canadian Journal of Public Health / Revue Canadienne De Sante'e Publique, 97, S4-S10.

Daley, A., Burton, P., \& Phipps, S. (2015). Measuring poverty and inequality in northern Canada. Journal of Children and Poverty, 21(2), 89-110. doi:10.1080/10796126.2015.1089147 
Dean, M. (2010). Governmentality: Power and rule in modern society (2nd Ed.) SAGE.

Dean, M. (1999). Governmentality: Power and rule in modern society Sage

Publications.Harding, R. (2016). Limited and limiting conversations about the poor: Elizabethan prescriptions to poverty in the Canadian press. Canadian Review of Social Policy, (76), 25.

Evans, B. M., Shields, J., \& CERIS. (2005). The third sector: Neo-liberal restructuring, governance, and the remaking of state-civil society relationships Joint Centre of Excellence for Research on Immigration and Settlement.

Fimyar, O. (2008). Using governmentality as a conceptual tool in education policy research. Educate, 1(1), 3-18.

Hanson, C., \& Hanson, L. (2011). Unpaid work and social policy: Engaging research with mothers on social assistance. Action Research, 9(2), 179-198. Doi: 10.1177/1476750310388053

Gonzales, V. (2007). Globalization, welfare reform and the social economy: Developing an alternative approach to analyzing social welfare systems in the post-industrial era. Journal of Sociology and Social Welfare, 34(2), 187-211.

Harding, R. (2016). Limited and limiting conversations about the poor: Elizabethan prescriptions to poverty in the Canadian press. Canadian Review of Social Policy, (76), 25.

Hay.D. I. \& Canadian Council on Social development, (2009). Poverty reduction policies and programs, in Canada Canadian Council on Social Development;

Hulchanski, J. D. (2010). The three cities within Toronto: Income polarization among Toronto's neighbourhoods, 1970-2005. 
Hulchanski, J. D., \& Shapcott, M. (Eds.). (2004). finding room: Policy options for a Canadian rental housing strategy. Toronto, Ontario, Canada

KERR, D., \& BEAUJOT, R. (2003). Child poverty and family structure in Canada, 1981-1997. Journal of Comparative Family Studies, 34(3), 321-335.

Kim, J. W., \& Choi, Y. J. (2013). Feminisation of poverty in 12 welfare states: Consolidating cross-regime variations? Feminisation of poverty in 12 welfare states. International Journal of Social Welfare, 22(4), 347-9

Kirkpatrick, S. I., \& Tarasuk, V. (2010). Assessing the relevance of neighbourhood characteristics to the household food security of low-income Toronto families. Public Health Nutrition, 13(7), 1139-1148.

Kwok, S., \& Tam, D. M. Y. (2010). Rethinking the role of municipal governments on redistribution in Ontario, Canada. Journal of Policy Practice, 9(2), 69-79. Doi: $10.1080 / 15588741003618144$

Leach, A., \& Ontario. (1997). Bill 103 (chapter 2, statutes of Ontario, 1997): An act to replace the seven existing municipal governments of metropolitan Toronto by incorporating a new municipality to be known as the city of Toronto Printed by the Legislative Assembly of Ontario. Legislative assembly of Ontario Bill 103, City of Toronto Act, 1997

Li, T. M. (2007). Governmentality. Anthropological, 49(2), 275-281.

Mahon, R., \& Macdonald, L. (2010). Anti-poverty politics in Toronto and Mexico City. Geoforum, 41(2), MCEWEN, A., \& STEWART, J. M. (2014). The relationship between income and children's outcomes: A synthesis of Canadian evidence. Canadian Public Policy / Analyse De Politiques, 40(1), 99-109. 
MCEWEN, A., \& STEWART, J. M. (2014). The relationship between income and children's outcomes: A synthesis of Canadian evidence. Canadian Public Policy / Analyse De Politiques, 40(1), 99-109.

McMullin, J. A., Davies, L., \& Cassidy, G. (2002). Welfare reform in Ontario: Tough times in mothers' lives. Canadian Public Policy / Analyze De Politiques, 28(2), 2

Milligan, K., \&Stabile, M. (2007).The integration of child tax credits and welfare: Evidence from the Canadian national child benefit program. Journal of Public Economics, 91(1), 305356.doi:10’1016/j.jpubeco.2006.05.008

Mullaly, R. P. (2002). Challenging oppression: A critical social work approach Oxford University Press.

Pratt, G. (1986). Housing tenure and social cleavages in urban Canada. Annals of the Association of American Geographers, 76(3), 366-380.

Rothwell, D., \& Robson, J. (2018). The prevalence and composition of asset poverty in Canada: 1999, 2005, and 2012: Asset poverty in Canada. International Journal of Social Welfare, 27(1), 17-27. doi:10.1111/ijsw.12275

Rose, N., \& Miller, P. (2010). Political power beyond the state: Problematics of government. The British Journal of Sociology, 61(s1), 271-303. doi:10.1111/j.1468-4446.2009. 01247.x

Skelton, I. (1996). The geographic distribution of social housing in Ontario, Canada: Comparing public housing and locally sponsored, third sector housing. Housing Studies, 11(2), 189-206.

Skelton, I. (1997). Planning under welfare pluralism: Social housing targets and allocations in Ontario, Canada. Geoforum, 28(1), 79-89. 
Stairs, F. (1999). The Canada child tax benefit: Income support and tax system. Journal of Law and Social Policy, 14.123.

Jackson, A. (2004). Asset-Based Social Policies - A "New Idea" Whose Time has come. Caledon Commentary. (pp. 1-5)

Ontario federation of labor presents special women's briefing. (2017). Professional Services Close-Up,

Statistics Canada. 2007. 2006 Census Dictionary. Statistics Cañada Catalogue no. 92-566-XWE. Ottawa, Ontario. February 14.

Toronto (Ont.) (2000). City of Toronto: Toronto maps. City of Toronto

Yeates, N. (2002). Globalization and social policy: From global neoliberal hegemony to global political pluralism. Global Social Policy, 2(1), 69-91.doi:10.1177 